\title{
PASSENGER TRANSPORT BY THE REICHSPOST VEHICLES DURING THE INTERWAR PERIOD, AS EXEMPLIFIED BY THE EASTERN PROVINCES
}

\author{
ANDRZEJ MIELCAREK \\ University of Szczecin, Faculty of Management and Economics of Services, POLAND \\ e-mail: andrzej.mielcarek@wzieu.pl
}

\begin{tabular}{l|l} 
RECEIVED & 6 November 2018 \\
ACCEPTED & 3 December 2018 \\
JEL & \\
CLASSIFICATION & N70, N90, N94
\end{tabular}

KEYWORDS vehicle transport of passengers, Reichspost, eastern provinces of Germany

ABSTRACT Passenger transport by the Reichspost vehicles during the interwar period, as exemplified by the Eastern Provinces. The aim of the article is to present the way in which the Reichspost gained a dominant position in regular passenger transport outside cities. It is done by analysing archival sources, statistics, reports of companies and institutions, as well as the subject literature. After World War I, military vehicles were adapted for civil use. In 1919 automobile companies called KVGs (Kraftverkehrsgesellschaft) were created, operating in provinces and lands of the Reich. KVGs were also created in Prussian provinces of Eastern Prussia, Pomerania, Brandenburg and Silesia. They were owned by the Reich as well as local governments. For the German Post (Deutsche Reichspost - DRP) passenger transport connected with postal shipments was an important source of income. For this reason the DRP was interested in keeping the passenger transport services for itself. In its dispute with the KVGs the DRP presented itself as an institution opposing the decentralization tendencies within the Reich. Because of poor financial results KVG Marken and Schlesien were liquidated the end of the 1920s. State legislation gave the DRP a privileged position since it did not have to obtain permission to create passenger routes. A matter of significance was to regulate the relationship with the Deutsche Reichsbahn (RB). The arrangements with the Railway in the second half of the 1930s gave the passenger vehicle transport to the DRP, while the RB maintained the vehicle transport of cargo with the exception of postal shipments. The DRP thus gained the dominant position in regular passenger transport outside cities. It was shown that the DRP achieved this position thanks to its agreement with the DR and the regulatory actions of the state.

\section{Introduction}

Regular passenger transport had been, until its mechanization (railways, steamships) the domain of the post since it used the fastest means of transport. However, at the beginning of the $20^{\text {th }}$ century the development of vehicle transport challenged that domination. While the postal cargo shipments were restricted to the post, the passenger transport on the roads became subject to competition from other carriers. The article shows on the basis 
of the analysed archival sources, statistics, reports of companies and institutions, as well as the subject literature, how the Reichspost attempted to gain advantage in regular vehicle services for passengers. The article deals with the areas of Eastern Prussia, Pomerania, Brandenburg (its eastern part), Lower and Upper Silesia.

The Constitution of the Reich, in force from 1919, decided on the unification of the post and telegraph service in Germany uniting three existing post managements of the Reich, Bavaria and Württemberg under one - the Deutsche Reichspost (DRP). It had come into effect by April 1920 (Sautter, 1951, p. 15).

\section{The Reichspost and the automobile companies}

Postal shipments together with passenger transport began in 1906 and 1907 in central and northern Germany. Road transport performed better in the mountainous areas of Bavaria and Wurttemberg. In 1912 the DRP also made successful attempts to operate in Thüringen. After the war began, however, the post buses were transferred to the army.(Sautter, 1951, pp. 103-104).

A significant role in the development of passenger and cargo transport was played by the army, private entrepreneurs and the Reichspost. Already in December 1918 the military vehicle fleet was transferred to civil Automobile Bureaus (Kraftverkehrsamt) existing in every province of Prussia and all lands of the Reich. They rented vehicles out relatively cheaply and the Reich financed them from war funds, however without considering depreciation. Spare parts came from wartime stock and worn out vehicles were replaced by new ones. Fuel costs were relatively low as well (APW OL AmCh, p. 40).

The Reich Treasury, attempting to lower the subsidies, decided that Automobile Bureaus would be replaced by public benefit organizations - Kraftverkehrs - Gesellschaft m.b. H. (KVGs). One such company covered an area of one Prussian province or a Reich land. It was forbidden to give away or sell their shares to private persons or firms. The partnerships included also the Reich, provinces, cities, districts and road maintenance institutions. This was a way to connect the interests of road and transport branches (APW OL AmCh, p. 40). The companies were supposed to solve day-to-day problems resulting from insufficiency of the railway, and strikes. It was also deemed necessary to maintain the whole of the vehicle fleet received from the army. There was a plan that at a suitable moment the provincial companies could join a central one which would, in turn, enable the State to take over its operation, once the political and economic situation became clear. The resolutions on establishing automobile companies were standard for every region. The share value was to be between 8 and 10 thousand marks per vehicle. The Reich had 25 to $49 \%$ share and was supposed to contribute fuel stations, workshops etc. in the form of loans. The proportion of shares of cities and kreis was determined with regard to their population. A profit of $4 \%$ of the share capital went to the shareholders. The Reich, which took upon itself the risk connected with the enterprise, had a right to veto resolutions made by shareholders and the board (APOIAmS, p. 9).

KVGs began to be created in February 1920. The Reich's share was 31\% in KVG Pommern, 32\% in KVG Ostpreussen, 34\% in KVG Marken in the Brandenburg province, 38\% in KVG Schlesien. The provinces' share amounted to several percent but in the Pomeranian province it was as much as $15 \%$. The rest was owned by cities and kreis in the amount usually dependent on their size and significance (APG AmG, No. 9217, p. 161).

Because of financial difficulties the KVGs began to be transformed into joint-stock companies in 1923. Apart from KVGs a significant share of the partnerships belonged to a Dresden fuel company Deutsche Betriebs - Akt.Ges (Debag) three quarters of which belonged to the State and which was the main supplier for the automobile 
companies. KV Marken, KV Nordmark and KV Schlesien became connected to Debag (APG AmG, No. 5028, k. 1, 371; APW OL AmCh, k. 83-84).

In the spring of 1920 the automobile postal routes were restored. However, the DRP's passenger transport was opposed by the automobile companies. In January 1919 the Reich government amended the VehicleTransport Act of 1909 with a statutory instrument. It made the operation of vehicleroutes dependent on a permission of central offices (district presidents). On the other hand, under the act of 1871, the DRP did not have such an obligation. This led to fierce competition harmful to both sides. In February of 1920 the government of the Reich decided that the Ministries of Post and Transport would agree on setting up new routes and determine which of them would be operated by the companies and which by the DRP. Both sides were supposed to coordinate timetables and ticket prices (Sautter, 1951, p. 104).

In 1920 the DRP had304 vehicle routes, totalling 6 thousand kilometres, and 428 buses. Transport performance totalled 4.6 million $\mathrm{km}$ and the number of persons carried- 4.1 million (Sautter, 1951, p. 105). In the autumn of 1920 the DRP maintained only a few postal passenger routes in the eastern provinces of Prussia: Bystrzyca KłodzkaMiędzygórze (15 km), Międzyzdroje-Międzywodzie (summerroute) (14 km), Demmin-Greifswald (38 km), DolicePyrzyce-Banie-Bolkowice-Widuchowa (64.4 km) (APS NPPP, No. 2166, k. 529).

Until 1924, postal passenger transport rose relatively slowly, however it doubled or even tripled between 1924 and 1925. The highest increase occurred between 1924 and 1925 when the number of routes rose from 593 to 1233 , their length increased to 24.7 thousand $\mathrm{km}$, and the number of passengers carried rose from 8.8 million to 24.8 million (Sautter, 1951, p. 105).

The position of theDRP in relation to other automobile carriers was strengthened by the Act of 1925 under which theDRP did not have to obtain permission for initiating regular services on a given route. It was, however, obliged to inform regional authorities about such a new service four weeks in advance. The authorities had a right to oppose the scheme if they decided that it did not serve the public interest. If an agreement could not be reached the case was referred to arbitration. Those rules referred both to postal routes and the passenger ones (Sautter, 1951, p. 105).

The Minister of Post argued that the increase of the DRP vehicle transport was caused by the rising horse transport costs and the possibility of restoring the services operated before the war thanks to vehicles obtained from the army. He also claimed that, in order to ensure profitability, the DRP had to combine mail shipments with passenger transport. Moreover, the DRP's transport services were supported by a wide network of post offices and its employees were regarded as more reliable than those in private companies (APS NPPP, No. 2166, k. 509-517). The Ministry stated that the main task of the KVGs was the transport of goods, not people. The KVGs developed passenger transport because the Reichsbahn (RB) was regaining its position in goods haulage and, at the same time, costs and wages were rising as well. Furthermore, the KVGs were also attacked with a political argument, relevant to the situation the Reich was in at the time. It was pointed out that the provincial or regional scope of vehicle companies' operations led to decentralization. The DRP, on the other hand, served the unity of the Reich as it covered the whole of its territory. For this reason it was argued that the Reich should withdraw its share from KVGs and once they were dissolved, the DRP should take over their staff and assets.(APS NPPP, No. 2167, k. 5).

The Union of Vehicle Companies (Verband Kraftverkehrsgesellschaften Deutschlands) claimed that the Reichspost should not compete with a company in which the Reich, cities and Kreis owned shares. Maintaining KVG and DRPservices on the same routes caused double wear of road surface, waste of fuel, materials and wages. 
They were prepared to fulfil the justified demands of the DRP referring to the Prussian act concerning the local railways (Kleinbahn) (APS NPPP, No. 2166, k. 463). The representative of the Pomeranian Province complained that the management of the DRP tried to persuade districts having share in the KVGs to subsidize the Reichspost's transport services (APS NPPP, No. 2166, k. 491-494).

An example of the competitive actions of the DRP may be the case of the Stargard-Suchan'-Wapnica route. Due to the resignation of a private entrepreneur, the mayor of Suchań requested help from KVG Pommern. After long negotiations the route was opened in September 1920. A month later the DRP started a Stargard-Recz route via Suchań. The Reichspost set a competitive price of 30 pf per km, later raised to 40 pf, in comparison to 50 pf charged by the KVG (APS NPPP, No. 2166, k. 504-506).

KVG Marken regarded the policy of the DRP as harmful to the interests of the State and local authorities and to be in conflict with the policies of other Reich ministries since the DRP had stopped cooperating with Marken and had started competing with it. Such a policy was approved by the Ministry of Post which, according to KVGs, was inconsistent with the pursuit of economies and the efforts to limit the prerogatives of central power in favour of the Reich regions (APG AmG, No. 9217, k. 147).

The actions of the DRP were also closely followed by the RB which strove to control them through state administration. Hence, for example, the President of the Legnica District asked Landrats and magistrates to inform the railway management of any talks with the DRP or private automobile companies on setting up vehicle services (APW OL, AmChnr, 1925r., k. 124).

It often happened that bus services could not be sustained especially in times of inflation when the rise in fuel prices was not matched by the rise in ticket prices. For this reason, in 1921, KVG Schlesien was prepared to transfer its bus services to the DRP. Eventually, in February of 1922, KVG Schlesien gave up its bus routes in the area of Post Directorates in Wrockaw and Opole and signed an appropriate agreement with the Post Directorate in Wrocław excluding the routes Wroclaw-Karłowice and Wrocław-Psary (APOp RO, No. 583, k. 114-115).

After the transformation into a listed company KV Schlesien did not feel obliged to respect the agreement of 1922. On the other hand, the Directorate of Post in Opole, which had already created 50 routes serving the needs of the postal and passenger transport, attempted to eliminate the competition of KV Schlesien (APOp RO, No. 583, k. 75). It protested against KV Schlesien being given a permission to operate the routes Gliwice-Sośnicowice and Kotlarnia-Koźle. The designed route was supposed to run partly alongside the Reichspost's route constituting unfair and unjustified competition (APOp RO, No. 583, k. 114-115).

In 1924, currency reform and difficulties in obtaining loans needed for the fleet renewal compounded the situation of the KVGs. In 1929 the KVG Schlesien AG was dissolved (APW OL AmCh, k. 127-134, 206, 215). Losses of KV Marken AG in 1926 and 1927 caused the shareholders to liquidate the company in 1928 which was approved by the Minister of Transport in 1930 (APG AmG, No. 5030, k. 284, 353, 355-356, 363).

\section{Reichspost and Reichshahn}

The competition between the Post and the Railway was supposed to be lessened by a five-year agreement signed in June 1929. It stated that passenger vehicle services would be run by the DRP. It did not concern, however, the routes opened before April 1 ${ }^{\text {st }}, 1929$. As for the routes created later, the parties agreed on their share in profits and losses and the overall percentage of their shares. While the agreement was in force, 122 jointroutes were set up. From June $1^{\text {st }} 1930$, the agreement ensured the smooth transfer of luggage and passengers between post 
offices existing along the postal routes and railway stations, as it had been between the horse post and the railway stations. In 1931, the joint transport system included 551 railway stations and 80 vehicle routes (Sautter, 1951, p. 105). The DRP was also taking over the vehicle route services of the RB from the KVGs. In December 1931 the Post took over the operations of 11 such routes from KVG Ostpreussen (Die Reichsbahn, 8 Jhg, H. 7, 17. 02. 1932, p. 182). The Reichsbahn and the Reichspost jointly maintained the vehicle services. In 1938 the agreement was dissolved with the provision that the Post would still, until May 1940, operate on its own 47 routes belonging to the Railway (Geschäftsbericht, 1937, p. 7).

Due to the growth of vehicle transport and its significance for the society the Minister of Post established four regional boards for vehicle services („Kraftfahr - Oberbetriebsleitungen” - KrOBL) as advisory bodies to the Post directorates. Wrocław was the headquarters of KrOBL Ost at the directorate of Potsdam, Frankfurt n/Oder, Legnica, Wrocław, Gąbiń, Königsberg, Koszalin, Szczecin, Schwerin (Meckl.) (Die Reichsbahn, 4 Jhg, H. 33, 15.08.1928, p. 742).

Anti-crisis decrees of the Reich President from October $10^{\text {th }} 1931$ included commercial services connected with vehicle transport. Permissions were required for regular passenger services between given places beyond commune borders and goods haulage for distances longer than $50 \mathrm{~km}$. It did not apply, however, to companies' transports for their own needs and with their own fleet. The compliance of transport activities with the regulations was determined by the DRP, RB, chamber of industry and commerce of the area where the company had its headquarters and representatives of automobile transport approved by the Ministry of Transport. Permissions for opening passenger vehicle services were given by local authorities in a given area if certain technical requirements were met and the public interest was not damaged. Other interested parties had to have their say as well. The DRP, however, was not subject to these regulations. It only had to notify the RB and local administration. Opinions concerning permissions for long-haul services had to be given by chambers of industry and commerce. The Minister of Transport set the fare for the whole of the Reich so that the railway and vehicle transport could operate following equal rules. At the same time, the Vehicle Services Act of 1925 ceased to apply (Reichsgesetzblatt, Teil I 1931, No. 67, TI. 5, Kap. V, pp. 558-561 in: APW RW No. I/9746, k. 1).

The Reichspost gained a dominant position in bus service operations as, for instance, in the case of the Wrocław district. In 1931, there were 138 routes in operation out of which 27 were private. Four bus routes belonged to tram companies and local railways. Most services (106) were operated by the Reichspost. 107 buses were in use making,in total, 3.4 million VKT (APW RW nr I 9796 k. 93-94).

Thanks to a wide network of postal transport services in 1930 the DRP and RB introduced direct passenger and luggage rail-post transport (Krapeiverkehr). It was thus possible to purchase a ticket for the whole route. Such passengers coming by train had priority on a post bus (Die Reichsbahn 6 Jhg, H. 21, 21.05.1930, pp. 611-613; Sautter, 1951, p. 65).

While the relations between the DRP and RB were, to a certain extent, settled, there still occurred competition with private carriers. For example, on the route between Gliwice and Sośnicowice a private entrepreneur took passengers away from the DRP. He thus violated $\$ 1$ of the Unfair Competition Act of June $7^{\text {th }}, 1909$ and if it happened before the regulation on long-haul vehicle services from October $6^{\text {th }} 1931$ also $\S \S 1$ and 8 of the Vehicle Services Act of August $26^{\text {th }}$ 1925. Interestingly, the businessman in question did not charge lower fares. The owner and the driver were forced to pay a fine, yet they did not cease their practices (APOp RO, I, No. 595, 1931, 1932). 
The Vehicle Passenger Transport Act of 1937 stated in its preamble that in the National Socialist Reich it is the state which takes care of the matters of transport. Public and private means of transport had to fulfil standard requirements, the same for the whole country, and every transport branch was supposed to take up tasks that it was best suited to. The act included also the DRP and RB. Like before, they did not need permission for regular route services. A four-week notice for the local authorities of a given area was sufficient. However, occasional passenger transport was prohibited. The Act referred to earlier regulations (1935) which stipulated that commercial transport distinguished passenger vehicles of fewer than 8 seats including the driver, omnibuses - eight and more seats, and also DRP's own vehicles which could not have more than a ton of capacity and four seats for passengers (Kraftfahrzeuggesetzgebung, 1942, p. 302, 308, 346-347).

Possessing the right for passenger transport, the DRP and RB decided, nevertheless, to separate their areas of activity. When the agreement of 1929 expired, long negotiations began in which the Reichsautobahnen took part as well. The consensus was reached in May, 1939. It stipulated that bus routes on motorways would be maintained by the RB and services on Reich roads and domestic roads would be operated by theDRP. This finished their joint operation of road passenger transport (Sautter, 1951, p. 106). It must be remembered that the Reichsbahn had a significant contributionto motorway construction and supported them both materially and financially.

The provinces became covered with a dense network of DRP long-haul vehicle routes and rural vehicle routes (Witt, 1934, Blatt 25; Geisler, 1932, Blatt 49). The first vehicle services of the rural post were established in 1928. For these services the Post ordered vehicles of the capacity not higher than one ton which could carry up to seven people (Deutsche Reichspost, 1928, p. 39; Buschmann, 1996, pp. 56-58). In the Eastern Directorates of the DRP (Królewiec, Gąbiń, Szczecin, Koszalin, Frankfurt n/O, Wrocław, Opole) the length of vehicle post routes amounted to 9.4 thousand kilometres and the rural routes -27.4 thousand $\mathrm{km}$. 9.6 million people were transported in total (Statistisches..., 1938).

\section{Conclusions}

The Reichspost's vehicle transport carried not only postal loads but also passengers. However, in this field of business the DRP had to compete with provincial and nationwide vehicle companies. In this rivalry the DRP presented itself as an institution opposing the decentralization tendencies within the Reich. Appropriate legislation finally enabled the Reichspost to limit the competition in the area of regular passenger services. In successive agreements the Reichsbahn left the passenger transport to the Reichspost while maintaining vehicle freight transport with the exception of the postal freight. Thus the Reichspost gained a dominant position in long-haul passenger transport and provided services in rural areas as well.

\section{References}

Buschmann, K. (1996). Alleskönner bei der Post. Die grosse Zeit der Landkraftposten. Post- und Telekommunikationsgeschichte, $54-67$.

Deutsche Reichspost. Geschäftsbericht über des Rechnungsjahr (1928). Berlin.

Die Reichsbahn, Amtliches Nachrichtenblatt der Deutschen Reichsbahn - Gesellschaft 4 Jhg. H. 33, 15.08.1928; 6 Jhg. H. 21, 21.05.1930; 8 Jhg, H. 7, 17.02.1932.

Geisler, W. (1932). Wirtschafts - und verkehrsgeographischer Atlas von Schlesien. Breslau: M \& H Marcus.

Geschäftsbericht der Deutschen Reichsbahn über das Geschäftsjahr 1937 (1938). Berlin.

Kraftfahrzeuggesetzgebung. Textausgabe (1942). Otto Nüssle, München u. Berlin. 
Sautter, K. (1951). Geschichte der Deutschen Post. Teil 3 Geschichte der Deutsche Reichspost (1871-1945). Bundesdruckerei, Frankfurt (Main).

Statistisches Jahrbuch für das Deutsche Reich (1938). Berlin.

Witt, W. (1934). Wirtschafts- und verkehrsgeographischer Atlas von Pommern. Stettin: Ostsee - Druck und Verlag A.-G.

Archiwum Państwowe (AP):

AP Gorzów, Akta m. Gorzów (APG AmG) No. 5028, 5030, 9217.

AP Olsztyn, Akta m. Szczytno (APOIAmS) No. 68

AP Opole, Rejencja Opolska (APOp RO) No. 583, 595.

AP Szczecin, Naczelne Prezydium Prowincji Pomorskiej (APS NPPP) No. 2166, 2167.

AP Wrocław, Rejencja Wrocławska (APW RW) No. I/9746, I/9796.

AP Wrocław Oddział Legnica, Akta m. Chojnów (APW OL AmCh) No. 171.

Cite this article as: Mielcarek, A. (2018). Passenger transport by the Reichspost vehicles during the interwar period, as exemplified by the Eastern Provinces. European Journal of Service Management, 4 (28/1), 207-213. DOI: 10.18276/ejsm.2018.28/1-26. 